\title{
BACTERIAL COMMUNITIES IN RHIZOSPHERE OF MAIZE STUDIED BY T-RFLP
}

\author{
KATARÍNA ONDREIČKOVÁ ${ }^{1 *}$, ANDREJ FICEK ${ }^{2}$, DANIEL MIHÁLIK ${ }^{1}$, MARCELA GUBIŠOVÁ ${ }^{1}$, \\ MARTINA HUDCOVICOVÁ ${ }^{1}$, HANA DRAHOVSKÁ ${ }^{2}$, JÁN KRAIC ${ }^{1,3}$
}

\author{
${ }^{1}$ National Agricultural and Food Centre \\ ${ }^{2}$ Comenius University in Bratislava \\ ${ }^{3}$ University SS. Cyril and Methodius, in Trnava
}

ONDREIČKOVÁ, K. - FICEK, A. - MIHÁLIK, D. - GUBIŠOVÁ, M. - HUDCOVICOVÁ, M. - DRAHOVSKÁ, H. KRAIC, J.: Bacterial communities in rhizosphere of maize studied by T-RFLP. Agriculture (Pol'nohospodárstvo), vol. 60 , 2014, no. 3, pp. 98-104.

\begin{abstract}
The terminal restriction fragment length polymorphism was used to determine the bacterial diversity in rhizosphere of maize (Zea mays L.) collected from four sites of experimental field plot in two dates of the vegetation season (July and September). The 16S rRNA gene was amplified from metagenomic DNA using universal eubacterial primers and PCR products were digested separately with three restriction enzymes. Significant differences in the number of terminal restriction fragments among rhizosphere samples and between sampling dates were not detected $(P<0.05)$. Variation within the bacterial com-
\end{abstract}

munities from different collecting places was evaluated by principal component analysis. Results showed that the most different bacterial community originated from marginal part of the experimental field plot collected in September was caused probably by combination of the marginal effect and drought before sampling date in September. Other rhizosphere samples showed from moderate to small differences in the structure of the bacterial community. Nevertheless, significant differences among all collected bacterial communities were not observed.

Key words: bacterial diversity, maize, rhizosphere, terminal restriction fragment, $16 \mathrm{~S}$ rDNA

The microbial diversity in soil is very complex and provides a huge resource for studies of new genes, metabolic pathways, and their products (Sharma et al. 2007). There are around $2.6 \times 10^{29}$ of prokaryotic cells in soil (Whitman et al. 1998), but most of them are located in rhizosphere, i.e. in soil in direct contact with plant roots. The composition of soil microbial community is affected by soil structure and geographic location (Gelsomino et al. 1999), size of soil particles (Ranjard et al. 2000), mineral composition (Carson et al. 2009), and agri- cultural practices (Benizri et al. 2007), while microbial activity is greatly influenced by roots of plants (Bais et al. 2006). The composition of root exudates depends on plant species and cultivar, plant developmental stage, growth substrate, and different stress factors (Uren 2000). The main components of root exudates from maize are sugars, organic acids, and amino acids $(65 \%, 33 \%$, and $2 \%$, respectively) (Baudoin et al. 2003) but changes in the composition of root exudates are possible due to different root exudates produced by different maize geno-

Mgr. Katarína Ondreičková, PhD. (*Corresponding author), Mgr. Daniel Mihálik, PhD., Mgr. Marcela Gubišová, PhD., Mgr. Martina Hudcovicová, PhD., doc. RNDr. Ján Kraic, PhD., National Agricultural and Food Centre - Research Institute of Plant Production, Bratislavská cesta 122, 92168 Piešt’any, Slovak Republic, E-mail: ondreickova@vurv.sk Mgr. Andrej Ficek, PhD., doc. RNDr. Hana Drahovská, PhD., Comenius University in Bratislava, Faculty of Natural Sciences, Mlynská dolina, 84215 Bratislava, Slovak Republic

doc. RNDr. Ján Kraic, PhD., University SS. Cyril and Methodius, in Trnava, Faculty of Natural Sciences, Nám. J. Herdu 2, 91701 Trnava, Slovak Republic 
types (Corrales et al. 2007). Therefore, rhizosphere is a highly dynamic environment and probably more factors may affect rhizobacterial community composition, making the rhizosphere more variable and thus unpredictable for the presence or absence of particular bacterial species (Buée et al. 2009).

Advanced tools for analysis of diversity within and among bacterial communities must be available and used to achieve relevant results from studies of soil microbial diversity and changes caused by biotic or abiotic factors. These methods should analyse also unculturable species of microbial community by culture-independent methods based on differences in DNA sequences. Such approaches based on amplification of targeted DNA fragments that are usually the $16 \mathrm{~S}$ ribosomal RNA (rRNA) gene or internal transcribed region spacer of the rRNA genes. Amplicons are eighter digested with restriction endonuclease before electrophoretic analysis (T-RFLP, Liu et al. 1997) or directly analysed by electrophoresis (ARISA, Denman et al. 2008), respectively.

The aim of this study was to evaluate differences among bacterial communities from maize rhizosphere collected at four different sampling sites within the experimental field plot and between two sampling dates, using culture-independent method, the terminal restriction fragment length polymor- phism (T-RFLP) targeted to PCR amplification of bacterial 16S rRNA gene.

\section{MATERIAL AND METHODS}

The field plot was located in Borovce (Experimental Station of the Research Institute of Plant Production, Pieštany, Slovak Republic). The basic climatic and soil parameters of experimental locality were: $167 \mathrm{~m}$ above sea level, average annual precipitation $593 \mathrm{~mm}(358 \mathrm{~mm}$ during the vegetation season), long-term average annual temperature $9.2^{\circ} \mathrm{C}$ (15.5 during the vegetation season). The soil characteristics of field plots were as follows: Haplic Chernozem. The depth of plow layer was $0.24-0.28 \mathrm{~m}$. The depth of mollic horizon was $0.40-0.55 \mathrm{~m}$; it was differentiated in the upper (eluvial) and under (illuvial) layer. In the depth of $0.50-0.85 \mathrm{~m}$, the mollic horizon proceeded into calciferous loess.

The maize hybrid DKC 3511 (Zea mays L.) was sown in the plot $62 \mathrm{~m} \times 200 \mathrm{~m}$. Pesticides were applied according to actual occurrence of diseases, pests, and weeds. Samples of rhizosphere were collected on July $29^{\text {th }}$ (samples RJ) and on September $23^{\text {rd }}$ (samples RS) from four positions within the plot - three were inside (samples R1, R2 and R3) and one at the margin of plot (sample R4). Rhizosphere

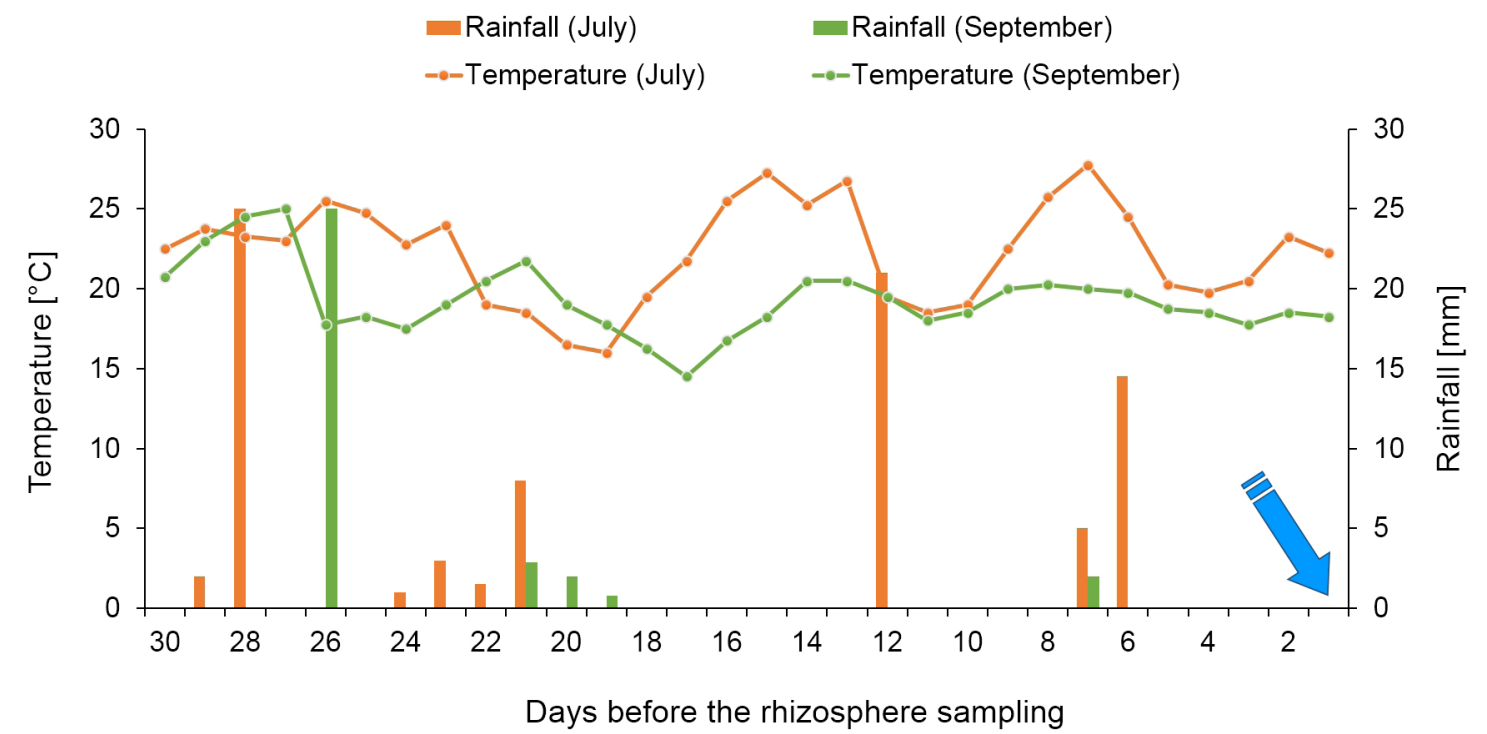

Figure 1. Precipitation and temperature at the field trial 30 days before the rhizosphere sampling; measured values represent monthly interval from $30^{\text {th }}$ June to $29^{\text {th }}$ July 2009 and $25^{\text {th }}$ August to $23^{\text {rd }}$ September 2009. The arrow indicates the sampling day 
samples collected in September were collected exactly from the same positions as in July. Daily precipitation and air temperature were measured during one month before sampling (Figure 1). Maize plants were taken out from soil, bulk soil from roots was removed and rhizosphere layers were taken from the roots and stored at $4^{\circ} \mathrm{C}$ in sterile tubes.

Collected samples of rhizosphere were homogenized and metagenomic DNA was extracted using the PowerSoil DNA Isolation Kit (MoBio Laboratories Inc., Carlsbad, USA). DNA amplifications were carried out in $50 \mu \mathrm{L}$ reaction mixtures containing $1 \times$ PCR buffer (Invitrogen, Thermo Fisher Scientific Inc., Waltham, USA), $1.5 \mathrm{mmol} \mathrm{Mg}^{2+}, 0.10 \mu \mathrm{mol}$ of both primers, $200 \mu \mathrm{mol}$ of each dNTP (Invitrogen, Thermo Fisher Scientific Inc., Waltham, USA), 1 U Taq DNA polymerase (Invitrogen, Thermo Fisher Scientific Inc., Waltham, USA), and $1 \mu \mathrm{L}(20 \mathrm{ng})$ of DNA extracted from soil. Bacterial universal primers for the 16S rRNA gene 8F (FAM labelled at the 5 '-end) (Edwards et al. 1989) and 926R (Muyzer et al. 1995) were used. Amplification of DNA by PCR was programmed as follows: initial denaturation for $3 \mathrm{~min}$ at $95^{\circ} \mathrm{C}$ followed by 35 cycles: $30 \mathrm{~s}$ at $94^{\circ} \mathrm{C}$, $30 \mathrm{~s}$ at $47^{\circ} \mathrm{C}, 1 \mathrm{~min}$ at $72^{\circ} \mathrm{C}$, and final polymeriza- tion for $10 \mathrm{~min}$ at $72^{\circ} \mathrm{C}$, using the GeneAmp PCR System 9700 (Applied Biosystems, Thermo Fisher Scientific Inc., Waltham, USA). Three separate PCR mixtures from each sampling point were pooled, and PCR products were purified by the PCR Purification \& Agarose Gel Extraction Combo Kit (Ecoli s.r.o., Bratislava, Slovakia). Cleavage of PCR products was performed separately using the restriction endonucleases $C f o \mathrm{I}, M s p \mathrm{I}$, and $R s a \mathrm{I}$ (Roche Slovensko s.r.o., Bratislava, Slovakia) in reaction mixture with total volume of $20 \mu \mathrm{L}$ and containing $10 \mathrm{U}$ of restriction enzyme, $1 \times$ buffer, and $10 \mu \mathrm{L}$ of purified PCR mix during $2 \mathrm{~h}$ at $37^{\circ} \mathrm{C}$. Samples after cleavage were purified using the same kit and samples were diluted to a concentration of $40 \mathrm{ng} / \mu \mathrm{L}$. Terminal restriction fragments (T-RFs) were separated by capillary electrophoresis using the ABI Prism 3100 Avant Apparatus (Applied Biosystems, Thermo Fisher Scientific Inc., Waltham, USA) with LIZ 1200 internal standard. Electrophoretograms were analyzed by GeneMapper 3.5 (Applied Biosystems, Thermo Fisher Scientific Inc., Waltham, USA). Only fragments in range 70-600 bp were used for evaluation.

Results were statistically evaluated by the Fisher's least significant difference (LSD) procedure at

$\begin{array}{cccccc}\mathrm{T} & \mathrm{a} & \mathrm{b} & 1 & \mathrm{e} & 1\end{array}$

Categories of T-RFs obtained after cleavage with $C f o \mathrm{I}, M s p \mathrm{I}$, and $R s a \mathrm{I}$

\begin{tabular}{|l|c|c|c|c|}
\hline \multirow{2}{*}{$\begin{array}{l}\text { Restriction } \\
\text { endonuclease }\end{array}$} & Ubiquitous T-RFs & Unique T-RFs & Other T-RFs & Total \\
\cline { 2 - 5 } & \multicolumn{3}{|c|}{ July/September } \\
\hline CfoI & $30 / 31$ & $36 / 37$ & $9 / 12$ & $75 / 80$ \\
Msp I & $17 / 29$ & $30 / 32$ & $12 / 7$ & $59 / 68$ \\
RsaI & $12 / 13$ & $25 / 13$ & $10 / 8$ & $47 / 34$ \\
\hline
\end{tabular}

$\mathrm{T}$ a $\quad \mathrm{b} \quad 1$ e 2

Number of unique T-RFs for each bacterial rhizosphere sample after cleavage with $C f o \mathrm{I}, M s p \mathrm{I}$, and $R s a \mathrm{I}$, collected in July and September

\begin{tabular}{|l|c|c|c|}
\hline \multirow{2}{*}{$\begin{array}{l}\text { Rhizosphere } \\
\text { sample }\end{array}$} & CfoI & MspI & \multicolumn{2}{|c|}{ July/September } \\
\cline { 2 - 4 } & \multicolumn{3}{|c|}{} \\
\hline R1 & $7 / 4$ & $14 / 9$ & $2 / 3$ \\
R2 & $6 / 9$ & $6 / 5$ & $1 / 1$ \\
R3 & $7 / 8$ & $7 / 13$ & $1 / 1$ \\
R4 & $16 / 16$ & $3 / 5$ & $21 / 8$ \\
\hline
\end{tabular}


the $95.0 \%$ confidence level. Bacterial communities in different samples were evaluated by the presence/ absence of specific T-RFs and the binary data was used for Principal Component Analysis (PCA) using the Statgraphics X64 statistical program.

\section{RESULTS AND DISCUSSION}

Diversity between communities of bacteria living in rhizosphere of maize hybrid DKC 3511 was studied using variation in the $16 \mathrm{~S}$ rRNA gene. The number of detected T-RFs among individual rhi- zosphere samples was different. The total number of resulted T-RFs was affected by restriction endonuclease used for generation of T-RFs, the highest number was detected for $C f o \mathrm{I}$, and the least for $R s a \mathrm{I}$. Within each of them, the differences in the number of T-RFs were higher in September than in July (Table 1). According to the occurrence, T-RFs were divided into three groups: 1 . ubiquitous T-RFs present in all four samples, 2. unique T-RFs present in only one sample, 3. other T-RF occurred in 2-3 samples. The unique T-RFs represented the largest part of the total number of T-RFs and represent specific species or groups of bacteria which also ensure varia- a)

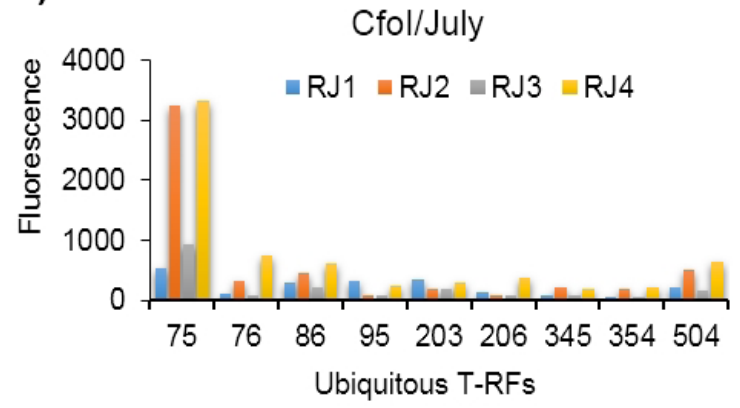

b)

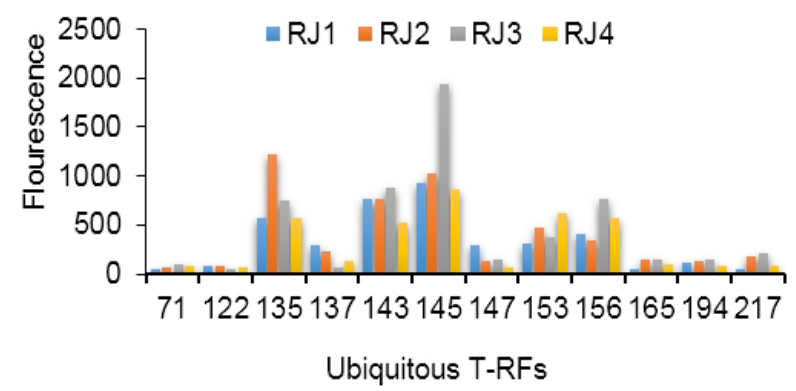

c)

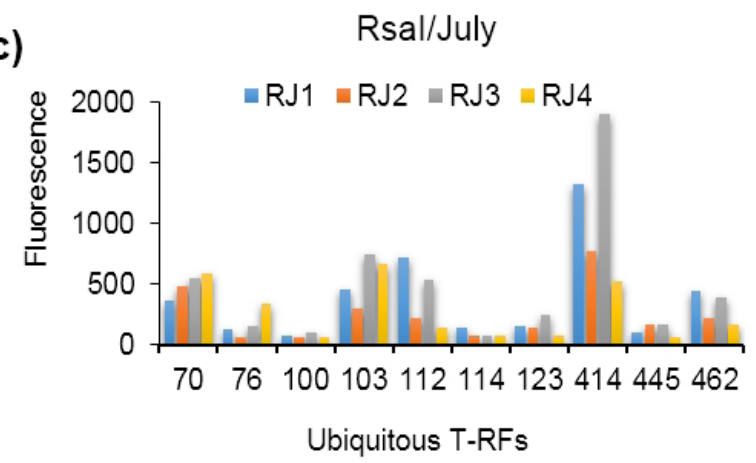

d)

e)
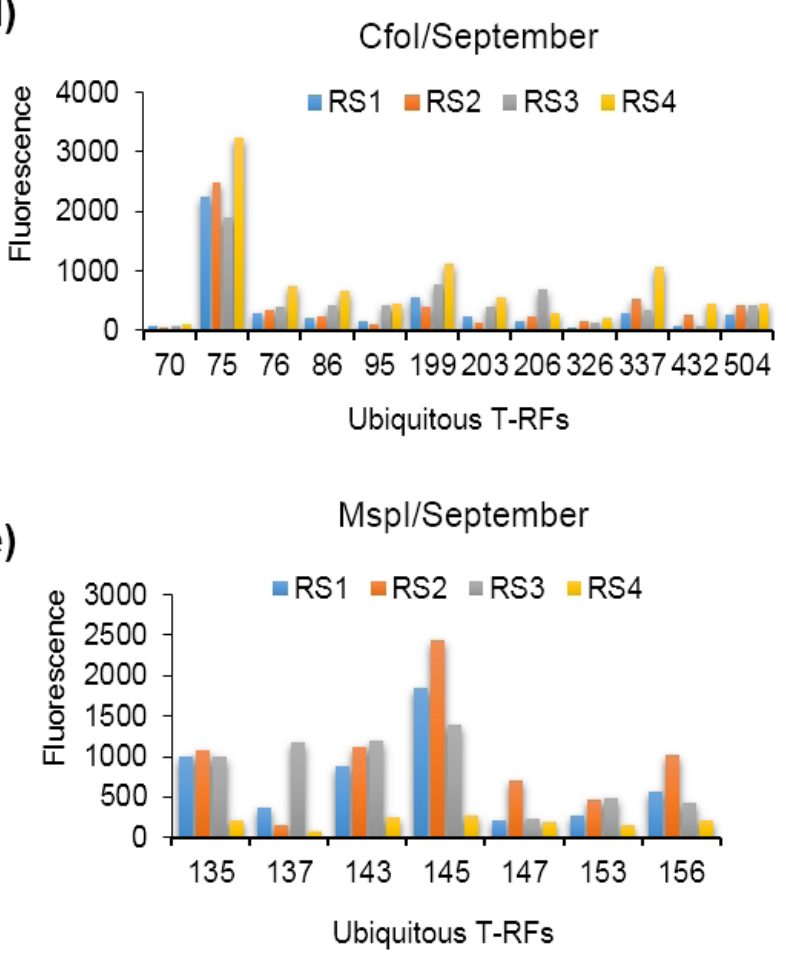

f)

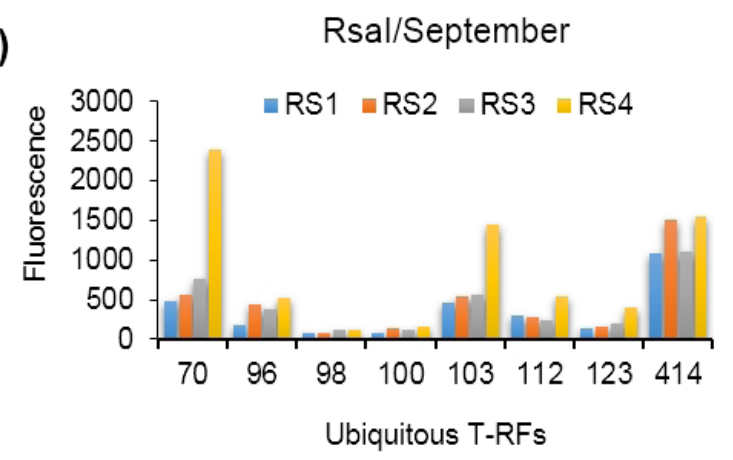

Figure 2. The intensities of the fluorescent signals of ubiquitous T-RFs different in length (bp) occurred in rhizosphere samples; a), b), c) - samples collected in July; d), e), f) - samples collected in September 


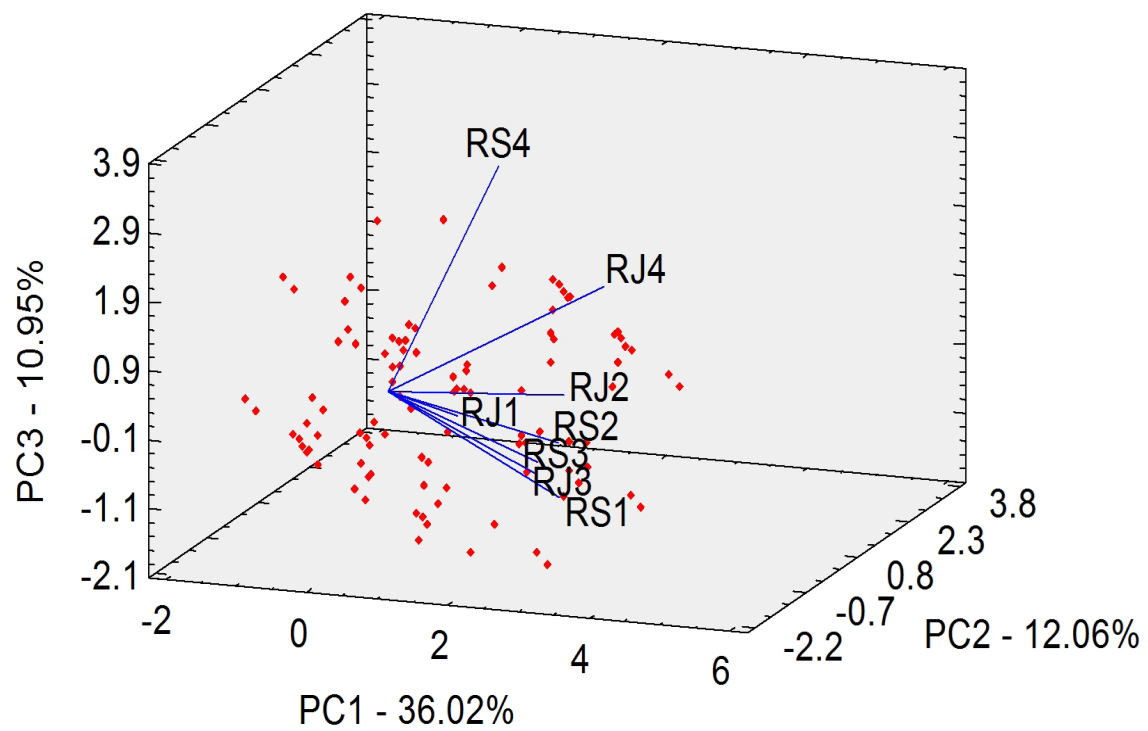

Figure 3. The PCA biplot of T-RFLP profiles from rhizosphere samples collected in July (RJ1-RJ4) and September (RS1-RS4) and digested with CfoI, MspI, and RsaI. The PCA biplot explained $59.03 \%$ of the variability in the data

tion among individual rhizosphere samples (Table 2). According to the total number of unique T-RFs, sample RS4 differed the most from others, nevertheless statistically significant differences among samples were not detected $(L S D, P>0.05)$ (Table 2).

The number of ubiquitous T-RFs and their abundance was different for each sample (Figure 2). The sizes of experimentally obtained ubiquitous T-RFs detected in both collection period were compared with in silico T-RFs of known bacteria using the program MiCA 3 and Soil database based on RDP r12u10 by Ru Li (Microbial Community Analysis III, Shyu et al. 2007). Most ubiquitous T-RFs correspond to the Proteobacteria group (specifically $95 \mathrm{bp}$, $203 \mathrm{bp}$ and $206 \mathrm{bp} / C f o \mathrm{I} ; 135 \mathrm{bp}, 143 \mathrm{bp}, 147 \mathrm{bp}$, $156 \mathrm{bp} / M s p \mathrm{I} ; 112 \mathrm{bp} /$ RsaI). Other ubiquitous T-RFs correspond to the Acidobacteria, Actinobacteria, Firmicutes and Bacteroidetes. They could reflect the most commonly occurring bacteria in maize rhizosphere or bacteria dominant in soil specific for experimental locality. Several T-RFs were dominant in both sampling dates, i.e. in July and September (e.g. T-RFs $C f o \mathrm{I} / \mathrm{July}$ and $C f o \mathrm{I} /$ September with length of $75 \mathrm{bp}$ ), others occurred only in July (e.g. RsaI/July with length of $462 \mathrm{bp}$ ) or only in September (e.g. $C f o \mathrm{I} / \mathrm{July}$ with length of $432 \mathrm{bp}$ ).

The principal component analysis (Figure 3) revealed high similarity of the T-RF profiles of rhi- zosphere bacterial communities from samples RJ1, RJ2, RJ3, RS1, RS2, and RS3. Bacterial community from RJ4 rhizosphere sample was slightly different, the RS4 was the most different from other samples. The reason is probably the marginal effect, i.e. position of sampling site located on the margin of experimental plot where condition and parameters in soil can be different in comparison with inner parts of field plot. Also climatic conditions could affect bacterial rhizosphere on the margin of field plot, especially in September when only very limited precipitation was during four weeks before rhizosphere sampling (Figure 1). It caused overdrying of soil mainly in marginal parts of the experimental plot. Simultaneously, obtained results indicate that lower precipitation in the second period of sample collection influences probably the changes in rhizosphere bacterial composition more than temperature variation in the first period of sample collection. This is particularly evident from position of the marginal samples RJ4 and RS4 in the PCA graph (Figure 3).

Obtained results revealed that changes in the structure and composition of the bacterial community in rhizosphere occur within the same genotype (DKC 3511) of maize as well as in different phases of plant growth (July, September). However, changes were not significant. This corresponds with results of Marschner and Rumberger (2004) which 
observed recolonisation of sterile soil with bacteria and concluded that the structure of bacterial community in rhizosphere is highly dynamic and can be changed within a few days. There are only few published studies of microbial diversity in maize rhizosphere using the T-RFLP method. Prischl et al. (2012) used the T-RFLP for study of endophytic bacterial community in seven maize cultivars (three of them were transgenic) and concluded that the maize cultivar impacted soil environment, regardless of transgenic or non-transgenic status. Similar results were also observed using T-RFLP method for study of rhizosphere bacterial communities in the conventional and genetically modified maize MON810 (Ondreičková et al. 2014). Cavaglieri et al. (2009) used culture-dependent methods and found significant changes in microbial community composition in maize rhizosphere during all growth stages. On the contrary Gomes et al. (2001), using the temperature gradient gel electrophoresis, revealed no changes in the composition of the bacterial community in rhizosphere at different growth stages in two maize cultivars but they observed significant seasonal changes in both cultivars. These changes were more pronounced from samples taken from young roots than from samples taken from mature plants. Also no significant changes were detected in maize rhizosphere between transgenic herbicide resistant maize and its isogenic line by single strand conformational polymorphism (Schmalenberger \& Tebbe 2002).

The rhizosphere plays very important role in plant nutrition and nutrient cycles, plant health, microorganism-mediated carbon sequestration, and ecosystem functioning. In addition to other biotic and abiotic factors, the root exudates influence rhizosphere microbial communities with impacts on agriculture production and nature conservation.

\section{CONCLUSION}

The terminal restriction fragment length polymorphism represents a powerful tool for studying of microbial communities from soil samples. Application of T-RFLP method in combination with principal component analysis or similar statistic analyses is very useful for detection and presentation of status of bacterial communities in rhizosphere and emerging changes. Results of this study demonstrated that although the composition of bacterial communities in rhizosphere of maize was too little different among samples collected from inner parts of field plot; these collected from maize plant grown in marginal part of plot were slightly different. This fact could be caused by modified soil parameters, especially after drought or very low precipitation. Nevertheless, these differences were not statistically significant.

Acknowledgements. This work was supported by the Operational Programme Research and Development for the project „Development and installation of lysimeters equipment for the rational farming on land in sustainable crop production (ITMS 26220220191)“ and „Systems biology for protection, reproduction and use of plant resources of Slovakia (ITMS26210120039)" co-financed from the resources of the European Regional Development Fund.

\section{REFERENCES}

BAIS, H.P. - WEIR, T.L. - PERRY, L.G. - GILROY, S. - VIVANCO, J.M. 2006. The role of root exudates in rhizosphere interactions with plants and other organisms. In Annual Review of Plant Biology, vol. 57, 2006, pp. 233-266. DOI: 10.1146/annurev.arplant.57.032905.105159.

BAUDOIN, E. - BENIZRI, E. - GUCKERT, A. 2003. Impact of artificial root exudates on the bacterial community structure in bulk soil and maize rhizosphere. In Soil Biology \& Biochemistry, vol. 35, 2003, pp. 1183-1192. DOI: 10.1016/S0038-0717(03)00179-2.

BENIZRI, E. - NGUYEN, C. - PIUTTI, S. - SLEZACK-DESCHAUMES, S. - PHILIPPOT, L. 2007. Additions of maize root mucilage to soil changed the structure of the bacterial community. In Soil Biology \& Biochemistry, vol. 39, 2007, pp. 1230-1233. DOI: 10.1016/j. soilbio.2006.12.026.

BUÉE, M. - DE BOER, W. - MARTIN, F. - VAN OVERBEEK, L. - JURKEVITCH, E. 2009. The rhizosphere zoo: An overview of plant-associated communities of microorganisms, including phages, bacteria, archaea, and fungi, and of some of their structuring factors. In Plant Soil, vol. 321, 2009, pp. 189-212. DOI: 10.1007/s11104-009-9991-3.

CARSON, J.K. - CAMPBELL, L. - ROONEY, D. CLIPSON, N. - GLEESON, D.B. 2009. Minerals in soil select distinct bacterial communities in their microhabitats. In FEMS Microbiology Ecology, 
vol. 67, 2009, pp. 381-388. DOI: $10.1111 /$ j.15746941.2008.00645.x.

CAVAGLIERI, L. - ORLANDO, J. - ETCHEVERRY, M. 2009. Rhizosphere microbial community structure at different maize plant growth stages and root locations. In Microbiological Research, vol. 164, 2009, pp. 391-399. DOI: 10.1016/j.micres.2007.03.006.

CORRALES, I. - AMENÓ, M. - POSCHENRIEDER, C. - BARCELÓ, J. 2007. Phosphorus efficiency and root exudates in two contrasting tropical maize varieties. In Journal of Plant Nutrition, vol. 30, 2007, pp. 887900. DOI: 10.1080/15226510701375085.

DENMAN, S.E. - NICHOLSON, M.J. - BROOKMAN, J.L. - THEODOROU, M.K. - MCSWEENEY, C.S 2008. Detection and monitoring of anaerobic rumen fungi using an ARISA method. In Letters in Applied Microbiology, vol. 47, 2008, pp. 492-499. DOI: $10.1111 / \mathrm{j} .1472-765$ X.2008.02449.x.

EDWARDS, U. - ROGALL, T. - BLÖCKER, H. - EMDE, M. - BÖTTGER, E.C. 1989. Isolation and direct complete nucleotide determination of entire genes: characterization of a gene coding for $16 \mathrm{~S}$ ribosomal RNA. In Nucleic Acids Research, vol. 17, 1989, pp. 7843 7853. DOI: $10.1093 / \mathrm{nar} / 17.19 .7843$.

GELSOMINO, A. - KEIJZER-WOLTERS, A.C. - CACCO, G. - VAN ELSAS, J.D. 1999. Assessment of bacterial community structure in soil by polymerase chain reaction and denaturing gradient gel electrophoresis. In Journal of Microbiological Methods, vol. 38, 1999, pp. 1-15. DOI: 10.1016/S0167-7012(99)00054-8.

GOMES, N.C.M. - HEUER, H. - SCHÖNFELD, J. COSTA, R. - MENDONÇA-HAGLER, L. - SMALLA, K. 2001. Bacterial diversity of the rhizosphere of maize (Zea mays) grown in tropical soil studied by temperature gradient gel electrophoresis. In Plant Soil, vol. 232, 2001, pp. 167-180. DOI: 10.1023/A:1010350406708.

LIU, W.T. - MARSH, T.L. - CHENG, H. - FORNEY, L.J. 1997. Characterization of microbial diversity by determining terminal restriction fragment length polymorphisms of genes encoding $16 \mathrm{~S}$ rRNA. In Applied and Environmental Microbiology, vol. 63, 1997, pp. 4516-4522.

MARSCHNER, P. - RUMBERGER, A. 2004. Rapid changes in the rhizosphere bacterial community structure during re-colonization of sterilized soil. In Biology and Fertility of Soils, vol. 40, 2004, pp. 1-6. DOI: 10.1007/s00374-004-0736-4.

MUYZER, G. - TESKE, A. - WIRSEN, C.O. 1995. Phylogenetic relationships of Thiomicrospira species and their identification in deep-sea hydrothermal vent samples by denaturing gradient gel electrophoresis of $16 \mathrm{~S}$ rDNA fragments. In Archives of Microbiology, vol. 164, 1995, pp. 165-172. DOI: 10.1007/ BF02529967.

ONDREIČKOVÁ, K. - MIHÁLIK, D. - FICEK, A. HUDCOVICOVÁ, M. - KRAIC, J. - DRAHOVSKÁ, H. 2014. Impact of genetically modified maize on the genetic diversity of rhizosphere bacteria: A two year study in Slovakia. In Polish Journal of Ecology, vol. 62, 2014, pp. 67-76.
PRISCHL, M. - HACKL, E. - PASTAR, M. - PFEIFFER, S. - SESSITSCH, A. 2012. Genetically modified Bt maize lines containing cry $3 \mathrm{Bb} 1$, cry $1 \mathrm{~A} 105$ or cry$1 \mathrm{Ab} 2$ do not affect the structure and functioning of root-associated endophyte communities. In $\mathrm{Ap}$ plied Soil Ecology, vol. 54, 2012, pp. 39-48. DOI: 10.1016/j.apsoil.2011.12.005

RANJARD, L. - POLY, F. - COMBRISSON, J. RICHAUME, A. - GOURBIÈRE, F. - THIOULOUSE, J. - NAZARET, S. 2000. Heterogeneous cell density and genetic structure of bacterial pools associated with various soil microenvironments as determined by enumeration and DNA fingerprinting approach (RISA). In Microbial Ecology, vol. 39, 2000, pp. 263-272. DOI: $10.1007 / \mathrm{s} 002480000032$.

SCHMALENBERGER, A. - TEBBE, C.C. 2002. Bacterial community composition in the rhizosphere of a transgenic, herbicide-resistant maize (Zea mays) and comparison to its non-transgenic cultivar Bosphore. In FEMS Microbiology Ecology, vol. 40, 2002, pp. 29-37. DOI: 10.1111/j.1574-6941.2002.tb00933.x.

SHARMA, P.K. - CAPALASH, N. - KAUR, J. 2007. An improved method for single step purification of metagenomic DNA. In Molecular Biotechnology, vol. 36, 2007, pp. 61-63. DOI: 10.1007/s12033-0070015-3.

SHYU, C. - SOULE, T. - BENT, S.J. - FOSTER, J.A. - FORNEY, L.J. 2007. MiCA: a webbased tool for the analysis of microbial communities based on terminal-restriction fragment length polymorphisms of $16 \mathrm{~S}$ and $18 \mathrm{~S}$ rRNA genes. In Journal of Microbial Ecology, vol. 53, 2007, pp. 562-570.

UREN, N.C. 2000. Types, amount, and possible functions of compounds released into the rhizosphere by soil-grown plants. In PINTON, R. - VARANINI, Z. - NANNIPIERI, P. (Eds.). The rhizosphere: biochemistry and organic substances at the soil-plant interface. New York: Marcel Dekker Inc., pp. 1-40. ISBN 0-8247-0427-4.

WHITMAN, W.B. - COLEMAN, D.C. - WIEBE, W.J. 1998. Prokaryotes: the unseen majority. In Proceedings of the National Academy of Sciences of the United States of America, vol. 95, pp. 6578-6583. Available online at http:www.pnas.org.

Received: August 26, 2014 